\title{
GEOGRAPHIC TONGUE IN A 6 YEAR OLD CHILD: A CASE REPORT WITH REVIEW OF LITERATURE
}

\author{
Dr. Punnet Bajaj ${ }^{1}$, Dr.Charu Kapoor ${ }^{2}$, Dr.Deepti Garg ${ }^{3}$, Dr.Rajeesh Mohammed P.K ${ }^{4}$, Dr. Robin \\ Sabharwal $^{5}$, Dr.Sharad Vaidya ${ }^{6}$ \\ ${ }^{1}$ Prof. \& Head, Department of Oral Pathology \& Microbiology, Bhojia Dental College, Distt. Solan, Himachal Pradesh (India) \\ ${ }^{2}$ Sr. Lecturer, Department of Oral Pathology \& Microbiology, Bhojia Dental College, Distt. Solan, Himachal Pradesh (India) \\ ${ }^{3}$ Reader, Department of Oral Pathology \& Microbiology, Bhojia Dental College, Distt. Solan, Himachal Pradesh (India) \\ ${ }^{4}$ Reader, Department of Oral Pathology \& Microbiology, Bhojia Dental College, Distt. Solan, Himachal Pradesh (India) \\ ${ }^{5}$ Sr. Lecturer, Department of Oral Pathology \& Microbiology, Bhojia Dental College, Distt. Solan, Himachal Pradesh (India) \\ ${ }^{6}$ Sr. Lecturer, Department of Prosthodontics and Implantology, Bhojia Dental College, Distt. Solan, Himachal Pradesh (India) \\ Corresponding Author: \\ ${ }^{2}$ Mobile: 919882429302 Email:chrkapoor@gmail.com
}

Received :
$27^{\text {th }}$ March, 2013
Accepted:
$18^{\text {th }}$ May, 2013
Available online:
$25^{\text {th }}$ August, 2013

Received :

$27^{\text {th }}$ March, 2013

Accepted:

Available online:

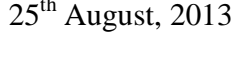

\begin{abstract}
Geographic tongue is an inflammatory disorder characterized by asymptomatic erythematoud patched with serpiginous borders. Clinically the appearance is of multifocal, circinate, irregular patches bonded by slightly elevated, white colored keratotic bands. Several etiological factors have been proposed. The conditions may remain asymptomatic or patients may present with complains of pain and burning sensation. We report a case of geographic tongue in a 6 year old boy with review of current concept in causes and management.
\end{abstract}

Keywords: Geographic tongue, Etiology, Cytology.

\section{INTRODUCTION}

Soft tissue oral and perioral lesion in the pediatric population are numerous and occur in the various clinical presentations. Geographic tongue is a transient and recurrent condition characterized by periodic localized loss of epithelium particularly of the filiform papillae on the dorsum of the tongue. The pattern of the red map like areas with white borders which occasionally migrate across the tongue gives an abnormal appearance resembling a map and may involve buccal mucosa. ${ }^{1}$ Several factors proposed as possible causative agents of geographic tongue, which include local factors, hormonal disturbances and various systemic diseases. Geographic tongue has a wide spectrum of appearance and variable symptomatology. The clinical presentation may vary from asymptomatic to a painful and burning ulceration. Management of geographic tongue depends upon the clinical presentation and the underlying etiology. ${ }^{1}$ We report a case of Geographic tongue in 6 years old boy with review of the current concept in causes and management.

\section{CASE REPORT}

A child patient aged 6years reported to the Department of Oral Pathology with a chief complaint of multiple lesions appearing on the tongue since 2 years. The location and pattern of the lesion changed with time. Patient also presented with burning sensation on eating hot and spicy food, which was associated with the lesion. Personal history revealed bottle feeding habit during night time.

Soft tissue examination revealed irregular red patches on the dorsal surface and lateral border of the tongue (Figure 1). The surface was smooth reddish pink or depapillated on dorsum and lateral border of tongue. These patches had a slightly elevated, thin white border, Based on the characteristic history of migration and clinical finding, diagnosis of geographic tongue was made.

Exfoliative cytology was done. Microscopic examination revealed exfoliated epithelial cells along with bacteria in the form of cocci arranged in chains and cluster. Few lymphocytes were also noted 
amongst these suggestive of focal areas of bacterial infection.

In our case as the child had symptoms of burning sensation on eating hot and spicy food, a supportive and symptomatic management was recommended. The treatment included included a bland diet, plenty of fluids, acetaminophen for systemic pain relief, and a topical anesthetic agent: lidocaine rinse for local pain relief.

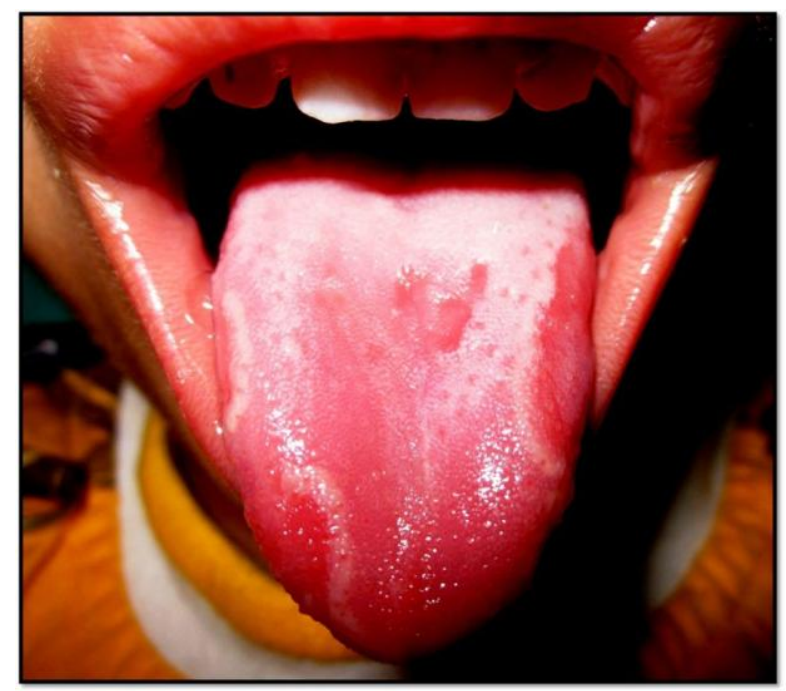

Figure 1: Depapillation of dorsal surface of tongue (Geograhic Tongue on Dorsal Surface of Tongue)

\section{DISCUSSION WITH REVIEW OF LITERATURE}

Benign migratory glossitis or geographic tongue is common benign disorder of unknown etiology. Erythema migrans is a benign, red and white condition that is commonly seen affecting the tongue. When the lesion appears on the dorsal surface or lateral borders of the tongue then the condition is referred to as geographic tongue. ${ }^{1}$

It affects the epithelium of the tongue characterized by the loss of filiform papillae leading to smooth ulcer like lesions that rapidly change the color and size. $^{2}$ The prevalence rate is between $1.0 \%$ and 2.5\%. ${ }^{3}$ According to Jainkttivong and Langlais ${ }^{4}$ the highest incidence of geographic tongue is in the 2029 age group. Shulman and Carpenter ${ }^{5}$ on the other hand found no relation between benign migratory glossitis and age among US adults. A higher female preponderance is reported. Jainkittivong and Langlais observed higher rates in females $(1.5: 1)$ between ages 9 and 79 in a population in Thiland. ${ }^{4}$ Similarly Marks and Simons reported a female to male ratio of 1.4:1 in the age group of 3 to 77 in an Australian population. ${ }^{6}$ Some authors on the other hand found that gender was not important to the incidence of geographic tongue. ${ }^{7}$

It is reported to begin in childhood and is most frequently observed in children four to four and half years of age. ${ }^{8}$ It is localized most commonly on the dorsum of the tongue, lateral borders and the tip of the tongue. It is characterized by discrete smooth reddened areas, usually slightly raised with pale yellow or white borders. When observed over a period of hours or days the denuded patches may change drastically in size and shape, often appearing to migrate across the surface of the tongue or disappearing for widely varying period of time. The pattern has been likened to land masses and oceans on a map, from which the synonym geographic tongue was derived. ${ }^{9,10}$

Hashemipour et al in a study of 837 students found that 104 students had geographic tongue. Most (74\%) lesions manifested a typical appearance consisting of a central atrophic area bounded by a raised white circinate line and the remaining lesions were characterized as solely atrophic patches. The most common site of the lesions was the lateral borders of the tongue. ${ }^{11}$

A process similar to geographic tongue when occurs in other areas of oral mucosa is called "ectopic geographic tongue". This was first described by Cooke (1955) under the mane of erythema migrans. ${ }^{12}$ In the literature several other names are also in use for this condition namely: geographic stomatitis ${ }^{13,14}$, stomatitis areata migrans ${ }^{15}$, erythema migrans ${ }^{16}$ and migratory stomatitis. ${ }^{17}$ It is emphasized that the ectopic geographic tongue is the same process as the geographic tongue involving other areas of the oral mucosa. ${ }^{18}$

The etiology and pathogenesis remains obscure. Many risk factors have been proposed including:

1. Hormonal disturbances ${ }^{19}$

2. Oral contraceptive use $\mathrm{e}^{20}$

3. Juvenile diabetes mellitus ${ }^{21}$

4. Pustular psoriasis ${ }^{22,23}$ 
5. Allergic conditions such as atopyhay fever and rhinitis $^{24,25}$

6. Fissured tongue $\mathrm{e}^{26,27}$

7. Robinow's syndrome ${ }^{28}$

8. Reiter's syndrome ${ }^{29}$

9. Down syndrome $\mathrm{e}^{30,31}$

10. Psychological factors ${ }^{32}$

11. Nutritional deficiencies ${ }^{33}$

12. Lithium therapy ${ }^{23,34}$

13. Familial predisposition ${ }^{35-37}$

14. FETAL hydantoin syndrome $\mathrm{e}^{38}$

15. Aarskog's syndrome. ${ }^{39}$

\section{HEREDITY}

A tendency for familial occurrence of this condition has been suggested. Redman et al reported a higher prevalence of benign migratory glossitis among first degree relatives of affected University of Minnesota students than among those of control students as well as among population from which the students were drawn. They suggested a polygenic model of hereditary transmission, with a threshold for susceptibility to environmental factors. ${ }^{10}$ Eidelman et al also suggested that geographical tongue is an inherited condition with a polygenic mode of condition. $^{27}$

\section{ASSOCIATION WITH PSORIASIS}

It has been proposed that benign migratory glossitis is an isolated oral manifestation of psoriasis rather than a mere association. ${ }^{40}$ The relationship of human leukocyte antigens (HLA) with psoriasis has been extensively investigated. Associations of HLA- Cw6 presents a particularly strong association irrespective of the racial or ethnic group suggesting that Cw6 itself or closely linked gene in strong linkage disequilibrium, is the major HLA-linked susceptibility gene for psoriasis. ${ }^{41}$ Wysocki and Daley reported the HLA phenotypes of seven patients with benign migratory glossitis and juvenile diabetes and found that none of the cases had Cw6 antigen and five had DR3 or DR4 which are the classical diabetes association. ${ }^{21}$ Marks and Tait in a study of ninety five patients with benign migratory glossitis found a marginal increase in the frequency of B15. ${ }^{42}$ Fenerly et al in a study of 50 Greek patients showed increased frequency of DR5 and DR6 and decreased frequency of $\mathrm{B} 51^{35}$ Gonzaga et al in a study of 22 patients reported a highly significant association of Cw6 with both psoriasis and benign migratory glossitis, with this antigen being present in $59.1 \%$ of the patients of psoriasis, $43.8 \%$ of the patients with benign migratory glossitis and in only $12.6 \%$ of the controls. $^{41}$ These reports reinforce the concept of a pathogenitic relationship between migratory glossitis and psoriasis.

Further histological findings and the parallel improvement of psoriatic skin lesion and tongue lesion with systemic retinoid treatment supports this hypothesis. The infiltrate in oral psoriatic lesions consists mainly of $\mathrm{T}$ cells and macrophages, particularly CD4 positive cells and immunehistochemical studies of geographic tongue show similar abundance of CD4 positive cells in the subepithelial cell infiltrate. ${ }^{43}$ However other researchers have reported that geographic tongue is uncommon in patients with psoriasis. ${ }^{44}$

\section{ALLERGY}

Patients with personal or family history of asthma, eczema and hay fever or elevated total serum immunoglobulin E levels may be more likely to have a geographic tongue. Psychosomatic factors, which probably contribute to both geographic tongue and atopy, may explain the high prevalence of this disorder in atopic patients. Goregen et al recently (2010) used patch test and prick tests to test different mechanisms associated with allergy. The skin prick test measures specific IgE anti bodies in the serum and is used to indicate sensitization. The patch test is helpful to determine delayed-type allergic reactions. The authors reported that performing both tests in combination improves the diagnostic efficacy of predisposition of allergy patients with benign migratory glossitis. ${ }^{45}$

Marks and Simons found a significantly increased frequency of atopy among patients with geographic tongue as compared to normal population. The prevalence of the HLA antigen B15 was found to be significantly elevated in cases with geographic tongue when compared to a normal population. ${ }^{6}$ McLendon and Jaeger reported children with milk allergy and stated that benign migratory glossitis occurred in a significant proportion of these patients. $^{46}$ 


\section{HORMONAL FACTORS}

It has been reported that hormonal fluctuations can affect the geographical tongue. The phase of the oral contraceptives cycle affected the initiation and duration of circinate lesions in women with geographic tongue; the changes were most severe on the day seventeenth of the cycle. ${ }^{20}$ Further about $8 \%$ of the patients with juvenile diabetes mellitus have a geographic tongue. ${ }^{21}$

\section{FISSURED TONGUE}

Geographic tongue occurs in association with fissured tongue. Milog lu et $\mathrm{al}^{9}$ reported a rate of $34.5 \%$, while Chosack et al determined a rate of $48.8 \%{ }^{47}$

\section{SMOKING}

The prevalence of geographic tongue is less among smokers. ${ }^{5,7}$ This observation could indicate a protective effect of smoking on benign migratory glossitis. ${ }^{9}$

\section{ASSOCIATION WITH SYNDROMES}

It may be associated with Reiter's syndrome, Down syndrome, Aarskog syndrome, Fetal hydantoin syndrome and Robinow's syndrome. ${ }^{28}$

Reiter's syndrome is characterized by the triad of urethritis, arthritis and conjunctivitis. The skin lesions may closely resemble those of psoriasis. ${ }^{48}$ oral lesions of Reiter's syndrome occur frequently. The lesions appear as gray or red papules which ulcerate, leaving erythematous or pigmented macules, shallow ulcers or more commonly oval flat erythematous areas with circinate border. The lesions, especially those of tongue closely resemble geographical tongue. ${ }^{49,50}$

Robinow's syndrome or fetal facies syndrome is a rare genetic disorder and includes a series of anomalies such as short stature, characteristic facial dysmorphism (fetal facies), genital hypoplasia, and mesomelic brachymelia. Cerqueira and de Souza described the orofacial manifestations of the Robinow's syndrome which included: triangular mouth and a long upper lip philtrum, ankyloglossia, a shortened tongue devoid of tongue tip, a geographic tongue, arched palate, gingival hyperplasia and dental abnormalities like misaligned and crowded teeth and delayed tooth eruption. ${ }^{28}$

Down syndrome is the most common chromosomal abnormality affecting numerous organs, including the skin. Daneshpazhooh et at studied the mucocutaneous findings in Down syndrome in 100 children attending Schools for Children with Special Educational Needs and centers affiliated to the Welfare and Rehabilitation Organization in two provinces of Iran. Mucocutaneous findings were noted in 61 and the authors reported that fissured tongue occurred in of $28 \%$ cases while geographic tongue in $4 \% .^{30}$

Ercis et al in a study of Seventy-one children with Down syndrome who were admitted consecutively to Hacettepe University Children's Hospital Genetics department reported fissured tounge in $20 \%$ case and geographic tongue in $11.2 \%$ cases. $^{31}$

The disease may also be considered part of the Aarskog syndrome along with Hirschprung disease, midgut malrotation, renal cyst and dental anamolies. $^{39}$ Geographical tongue may also be associated with Fetal hydantoin syndrome. ${ }^{38}$

\section{CLINICAL MANIFESTATIONS AND PATHOGENESIS}

The disease is characterized by periods of exacerbation and remission during which the lesions heal without residual scar formation. These periods of remission may last for days, months or years. ${ }^{1,2,4,9}$

The geographic tongue is usually diagnosed based on its unique clinical features and so its histopathological confirmation or biopsy is rarely needed. The treatment is aimed at reassuring the patient that the lesion are self limiting and benign. If the patient reports of symptoms of tenderness and burning, treatment in these cases is empiric. Topical steroids, mouth rinse of sodium bicarbonate in water, and diphenhydramine are helpful and reducing the symptom. ${ }^{1,10}$ 


\section{DIFFERENTIAL DIAGNOSIS}

Differential diagnosis includes candidiasis, psoriasis, Reiter's syndrome, leukoplakia, lichen planus, systemic lupus erythematosis, herpes simplex, and drug reaction. In children local trauma and severe neutropinia should be excluded. ${ }^{2}$ Candidiasis is the most common oral fungal infection in humans. Leukoplakia the most common premalignant lesion of oral mucosa is defined as a white patch or plaque that cannot be removed by vigorous scraping and cannot be classified as specific disease entity. ${ }^{51-53}$ The patients main concern in geographical tongue is that his/ her lesions could represent cancer leukoplakia should be considered a differential diagnosis. ${ }^{54,55}$

\section{TREATMENT}

Patients do not usually require treatment apart from reassurance. Various symptomatic treatments have been tried and include fluids, acetaminophen, mouth rinsing with topical anesthetic agent, antihistaminics, anxiolytics and steroids. ${ }^{2}$ Helfman reported satisfactory results after treating three patients with topical tretinoin. Vitamin A therapy resulted in partial improvement in some patients. ${ }^{56}$ The topical factors that exacerbate patient's symptoms such as very hot, spicy or acidic food, and dried salty nuts should be avoided. ${ }^{2}$ Abe et al reported marked improvement in a 54 year-old female with persistent and painful benign migratory glossitis (BMG), for about five years by systemic administration of cyclosporin. The systemic treatment of cyclosporin microemulsion pre-concentrate, $3 \mathrm{mg} / \mathrm{kg} / \mathrm{day}$, resulted in a satisfactory improvement. Two months later, patient was started on maintenance therapy with cyclosporin microemulsion pre-concentrate dosage to $1.5 \mathrm{mg} / \mathrm{kg} / \mathrm{day} .^{57}$

\section{CONCLUSION}

Geographic tongue is a benign condition that never turns into malignancy. There are also neither reported consequences nor risks associated with this condition. The only complication is the discomfort due to the persistent clinical appearance and frequent reccurence after healing. As the cause is unknown, the condition is not preventable. However it is advisable to promote optimal oral hygiene and avoid contact with local factors that could precipitate symptoms, such as spicy and acidic foods, alcohol, irritants in toothpastes and mouthrinses.

\section{REFERENCES}

1. Marks R, Radden BG. Geographic tongue: a clincopathology review. Australas J Dermatol 1981;22:75-9.

2. Assimakopoulos D, Patrikakos G, Fotika C, Elisaf M. Benign migratory glossitis or geographic tongue: an enigmatic oral lesion. Am J Med 2002;113:751-5.

3. Kovac-Kovacic M, Skaleric U. The prevalence of oral mucosal lesions in a population in Ljubljana, Slovenia. J Oral Pathol Med 2000;29:331-5.

4. Jainkittivong A, Langlais RP. Geographic tongue: clinical characteristics of 188 cases. J Contemp Dent Pract 2005;15:123-35.

5. Shulman JD, Carpenter WM. Prevalence and risk factors associated with geographic tongue among US adults. Oral Dis 2006;12:381-6.

6. Marks R, Simons MJ. Geographic tongue-a manifestation of atopy. Br J Dermatol 1979;101:159-62.

7. Avcu N, Kanli A. The prevalence of tongue lesions in 5150 Turkish dental outpatients. Oral Dis 2003;9:188-95.

8. Rioboo-Crespo Mdel R, Planells-del Pozo P, Rioboo-Garcia R. Epidemiology of the most common oral mucosal diseases in children. Med Oral Patol Oral Cir Bucal 2005;10:376-87.

9. Miloglu O, Goregen M, Akgul HM, Acemoglu H. The prevalence and risk factors associated with benign migratory glossitis lesions in 7619 Turkish dental outpatients. Oral Surg Oral Med Oral Pathol Oral Radiol Endod 2009; 107:e29-33.

10. Redman RS, Shapiro BL, Gorlin RJ. Hereditary component in the etiology of benign migratory glossitis. Am J Hum Genet 1972; 24:124-33.

11. Hashemipour M, Rad M, Dastboos A. Frequency, clinical characteristics and factors associated with geographic tongue. Shiraz Univ Dent J. 2008;9:83-92.

12. Cooke BE. Erythema migrans affecting the oral mucosa. Oral Surg Oral Med Oral Pathol 1955;8:164-7.

13. Hume WJ. Geographic stomatitis: a critical review. J Dent 1975;3:25-43.

14. Donelli RA. Geographic stomatitis (tongue and mucosae). J Clin Stomatol Conf. 1964;5:21-22.

15. Saprio SM, Shklar G. Stomatitis areata migrans. Oral Surg Oral Med Oral Pathol 1973;36:28-33.

16. Rood JP. An unusual presentation of erythema migrans. J Dent 1974;2:207-8.

17. Zingale JA. Migratory stomatitis: a case report. J Periodontol 1977;48:298-302.

18. Grinspan D, Fernandez Blanco G, Aguero S, Bianchi O, Stringa S. Ectopic Geographic tongue and AIDS. Int $\mathbf{J}$ Dermatol 1990;29:113-6.

19. Kullaa-Mikkonen A, Kotilainen R, Alakuijala P. Sialochemistry in mucosal lesions of the tongue: electrolytes and total protein. Int J Oral Maxillofac Surg 1986;15:31821

20. Waltimo J. Geographic tongue during a year of oral contraceptive cycles. Br Dent J 1991;171:94-6.

21. Wysocki GP, Daley TD. Benign migratory glossitis in patients with juvenile diabetes. Oral Surg Oral Med Oral Pathol 1987;63:68-70. 
22. Zhu JF, Kaminski MJ, Pulitzer DR, Hu J, Thomas HF. Psoriasis: pathophysiology and oral manifestations. Oral Dis 1996;2:135-44.

23. Zargari $\mathrm{O}$. The prevalence and significance of fissured tongue and geographical tongue in psoriatic patients. Clin Exp Dermatol 2006;31:192-5.

24. Marks R, Scaff CE, Yap LM, Verlinden V, Jolley D, Champell J. Fungiform papillary glossitis: disease in the mouth? Br J Dermatol 2005;153:740-5.

25. Marks R, Czarny D. Geographic tongue: sensitivity to the environment. Oral Surg Oral Med Oral Pathol 1984;58:1569.

26. Yarom N, Cantony U, Gorsky M. Prevalence of fissured tongue geographic tongue and median rhomboid glossitis among Israeli adults of different ethnic origins. Dermatology 2004;209:88-94.

27. Eidelman E, Chosack A, Cohen T. Scrotal tongue and geographic tongue: polygenic and associated traits. Oral Surg Oral Med Oral Pathol 1976;42:591-6.

28. Cerqueira DF, de Souza IP. Orofacial manifestations of a patient with Robinow's syndrome: a case report in pediatric patient. Oral Surg Oral Med Oral Pathol Oral Radiol Endod 2008;105:353-7.

29. Fotiou G, Laskaris G. Reiter's syndrome oral manifestations. Hell Stomatol Chron 1988;32:148-51.

30. Daneshpazhooh M, Nazemi TM, Bigdeloo L, Yoosefi M. Mucocutaneous findings in 100 children with Down syndrome. Pediatr Dermatol 2007;24:317-20.

31. Ercis M, Balci S, Atakan N. Dermatological manifestations of 71 children admitted to clinical genetics unit. Clin Genet 1996;50:317-20.

32. Redman RS, Vance FL, Gorlin RJ, Peagler FD, Meskin LH. Psychological component in the etiology of geographic tongue. J Dent Res 1966;4:1403-8.

33. Banoczy J, Szabo L, Csiba A. Migratory glossitis. A clinical- histological review of seventy cases. Oral Surg Oral Med Oral Pathol 1975;39:113-21.

34. Patki AH. Geographic tongue developing in a patient on Lithium Carbonate therapy. Int J Dermatol 1992;31:368-9.

35. Fenerli A, Papanicolaou S, Papanicolaou M, Laskaris G. Histo combatibility antigens and geographic tongue. Oral Surg Oral Med Oral Pathol 1993;76:476-9.

36. Pavelic J, Gall-Troselj K, Mravak-Stipetic M, Pavelic K. The p53 and nm23-H1 genes are not deleted in oral benign epithelial lesions. Anticancer Res 1998;18:3527-31.

37. Eidelman E, Chosack A, Cohen T. Scrotal tongue and geographic tongue: polygenic and associated traits. Oral Surg Oral Med Oral Pathol 1976;42:591-6.

38. Nanda A, Kaur S, Bhakoo ON, Kapoor MM, Kanwar AJ. Fetal hydantoin syndrome: a case report. Pediatr Dermatol 1989;6:130-3.

39. Hassinger DD, Mulvihill JJ, Chandler JB. Aarskog's syndrome with Hirschprung's disease, midgut malrotation and dental anomalies. J Med Genet 1980;17:235-8.
40. Pogrel MA, Cram D. Intraoral findings in patients with psoriasis with a special reference to ectopic geographic tongue (erythema circinata). Oral Surg Oral Med Oral Pathol 1988;66:184-9.

41. Gonzaga HF, Torres EA, Alchorne MM, Gerbase-Delima M. Both psoriasis and benign migratory glossitis are associated with HLA-Cw6. Br J Dermatol 1996;135:368-70.

42. Marks R, Taitt B. HLA antigens in geographic tongue. Tissue Antigens 1980;15:60-2.

43. Espelid M, Bang G, Johannessen AC, Leira JI, Christensen O. Geographic stomatitis: report of 6 cases. J Oral Pathol Med 1991;20:425-8.

44. Hietanen J, Salo OP, Kanerva I, Juvakoski T. Study of the oral mucosa in 200 consecutive patients with psoriasis. Scand J Dent Res 1984;92:50-4.

45. Goregen M, Melikoglu M, Miloglu O, Erdem T. Predisposition of allergy in patients with benign migratory glossitis. Oral Surg Oral Med Oral Pathol Oral Radiol Endod 2010;110:470-4.

46. McLedon PA, Jaeger DS. Milk intolerance, the cause of a nutritional entity: a clinical study. South Med J 1943;36:571-5.

47. Chosack A, Zadik D, Eidelman E. The prevalence of scrotal tongue and geographical tongue in 70359 Israeli schoolchildren. Community Dent Oral Epidemiol 1974;2:253-7.

48. Wright V, Reed WB. The link between Reiter's syndrome and psoriatic arthritis. Ann Rheum Dis. 1964;23:12-21.

49. Kulka JP. The lesions of Reiter's syndrome. Arthritis Rheum 1962;5:195-201

50. Weathers DR, Baker G, Archard HO, Brukes EJ Jr. Psoriasiform lesions of the oral mucosa (with emphasis on "ectopic geographic tongue"). Oral Surg Oral Med Oral Pathol 1974;37:872-88.

51. Sigal MJ, Mock D. Symptomatic benign migratory glossitis: report of two cases and literature review. Pediatr Dent 1992; 14:392-6.

52. Plackova A, Skach M. The ultrastructure of geographic tongue. Oral Surg Oral Med Oral Pathol 1975;40:760-8.

53. Kullaa-Mikkonen A. Geographic tongue: an SEM study. J Cutan Pathol 1986;13:154-62.

54. Binmadi NO, Jham BC, Meiller TF, Scheper MA. A case of deeply fissured tongue. Oral Surg Oral Med Oral Pathol Oral Radiol Endod 2010;109:659-63.

55. Greer RO. Pathology of malignant and pre-malignant oral epithelial lesions. Otolaryngol Clin North Am 2006;39:24975.

56. Helfman RJ. The treatment of geographic tongue with topical Retin-A solution. Cutis 1979;24:179-80.

57. Abe M, Sogabe Y, Syuto T, Ishibuchi H, Yokoyama Y, Ishikawa O. Successful treatment with cyclosporine administration for persistent benign migratory glossitis. J Dermatol 2007;34:340-3. 